Title: Is Innovation a sound justification for Medical Patents?

Author(s): Dara Tuncel

Source: St Andrews Law Journal, 1:1 (November 2020), 63-72

Published by: Institute of Legal and Constitutional Research, University of St Andrews

DOI: https://doi.org/10.15664/stalj.vii1.2348

This work is protected under Creative Commons Attribution 4.0 International (CC BY 4.0) License 2021.

The Author(s) retain copyright holding, having permitted the St Andrews Law Journal to distribute (publish) their work. All written content, Copyright @ the Author(s)

The St Andrews Law Journal is an Open Access publication of the University of St Andrews, published by the Institute of Legal and Constitutional Research with support from the University of St Andrews Journal Hosting Service

All use subject to:

https://creativecommons.org/licenses/by/4.0/

ISSN 2634-5102 


\section{Is Innovation a sound justification for Medical Patents?}

By Dara Tuncel

|Preamble|

| This essay will interrogate the legality of medical patents, arguing that one ought to reject the traditional utilitarian framework often used to justify IP law. Instead, this essay will turn to a more deontological justification for IP rights in UK law. |

While normal patents already come under much scrutiny on account of having quite restrictive effects on the market, medical patents are highly controversial and easy targets because of their perceived ability to directly harm someone's right to life by gatekeeping life-saving medicine. Since the start of the AIDS epidemic there has been a particularly harsh backlash against the existence of medical patents, with some companies even voluntarily giving away required medication to poorer countries. With the advent of COVID-19, and the international rush of countries vying to secure distribution rights for a viable vaccine produced by private sector companies, it seems an especially prudent time to consider the validity and justification behind drug patents in the United Kingdom. This essay will critically analyse the argument that drug patents encourage innovation and are a net benefit to society. This argument is strong on two counts; it not only is within the spirit of historical and contemporary intellectual property law in the UK and EU, but it also is an argument that especially fits the field of medical IP law.

This investigation will be composed of two parts. First it will go over the theoretical and empirical grounding behind the justification of medical patents. Before anything else it is essential to argue and prove that it is justified to give companies who develop new medicines almost monopolistic rights over the invention for a relatively long period of time. For the sake of brevity, it will analyse this through a utilitarian point of view. Second, it will then describe some key landmarks in British IP law and show how our argument is within the spirit of this legislation. 
The first modern patent legislations worth mentioning - following the 'Paris Convention for the Protection of Industrial Property (1883)', which defines the types of most commonly used patent protections as 'Collective Marks': Industrial Designs, Trade Names, Indications of Source, and Unfair Competition ${ }^{1}$ - are the 'Patents and Designs Act (Hansard) 1919' (succeeding the 'Patents and Designs Act, 1907/Principal Act'), and the 'Patents Act 1949'. The 1919 Act, among other things, gave a sixteen-year monopoly to patents and allowed for the granting of compulsory licenses three years after the granting of the patent. For the time this was not an uncommon part of patent legislation. This was exacerbated by the 1949 act which, with sections 41 and 46, allowed for a compulsory license immediately after the granting of a patent on behalf of or in service of any Government department and any person authorised in writing by the British Crown ${ }^{2}$. Furthermore, sections 14 and 33 allowed for opposition to the granting of a patent and the ability to seek its revocation. The suggested grounds for opposing a patent; "Lack of novelty, prior publication and ambiguous or imprecise specification". 3 The reason for these specifications is clear. The act, though it may have unintentionally harmed innovation through the compulsory license clauses, still suggested that patents were meant to be "novel" and innovate. Similarly, the 1977 Patents Act shows some ways in which innovation is valued as an important part of patenting. Section '1(1) of the act includes two interesting requirements for the granting of a patent: "a) The invention is new; b) it involves an inventive step". Furthermore, Section '1 (2) a)' prohibits the patenting of a "discovery, scientific theory or mathematical method"4. One example of this is that though methods of identifying an illness are not patentable if done through the human body, a company can still patent in vitro determination of laboratory parameters. Furthermore, EPO case law later establishes, in a different interpretation, that "diagnostic methods practices on the human body" should not be considered to relate only to methods containing all the steps involved in reaching a

\footnotetext{
${ }^{1}$ World Intellectual Property Organization, Summary of the Paris Convention for the Protection of Industrial Property (1883)

${ }^{2}$ Legislation.Gov, "Patents Act 1949" < https://www.legislation.gov.uk/ukpga/Geo6/12-13-

14/87/contents>

${ }^{3}$ Slin, Patents and the UK Pharmaceutical industry between 1945 and the 1970s, page.194

4 Legislation. Gov, "Patents Act 1977" < https://www.legislation.gov.uk/ukpga/1977/37/section/1>
} 
medical diagnosis, but to all methods practised on the human body which related to diagnosis or were of value for the purpose of diagnosis' (EPO TBoA T964/99, 2001, Cygnus), the caveat being that if one step had diagnostic importance and 'essential', then the procedure would be exempt from patenting5. According to recent estimates, patents were granted, or applications filed for almost $20 \%$ of human genetic data, including data for monogenic disorders such as Cystic fibrosis, and more common predisposition genes such as breast cancer6. In summary, the current medical patents legislation ensures that patents are first and foremost innovative inventions not discoveries - which deserve special protection. In the case of legislating and patenting medicine, it is clear novel drugs meet the criteria and spirit of the act. Novel drugs aren't simply new discoveries of existing product but are entirely new creations that required large quantities of capital and work to invent.

Novel techniques of medical practice and research should be delicately assessed to measure their quality and effectiveness prior to acceptance for clinical application. The Utilitarian Framework - or the 'egalitarian principle' - argues that for a practice (or law) to be 'good', it must produce the maximum amount of happiness and prosperity for all people. In the case of medical patents, utilitarianism promotes a systems of rewarding heath care innovations vis-à-vis the possibilities of the public health care system7. This can, however, encourage the suggestion that medical patents are unjustified because the monetary reward received by companies for Research and Development (R\&D) does not weigh-equally - in the sense of healtheconomical calculations - with the potential lives saved through either an insurance-cap based healthcare or free access to medicine via national taxbased subsidies. Utilitarianism, in this context, is not just a philosophical framework but also an economic and political one. Thus, understanding the true purpose of utilitarianism in the medical context is critical to determining whether current laws are acceptable, fulfil and go beyond historic ambitions.

5 Van Overwalle, IPR Issues and High Quality Genetic Testing, p256

${ }^{6}$ Soini (et.al) Patenting and licensing in genetic testing: ethical, legal and social issues, p10

7 Ibid, p34 
This is a primarily pragmatic framework, accepting that even if an act may result in some negative socio-economic consequences, patents applied to secure diagnostic tests - for example - can ensure that patients get tested, for prenatal or predictive purposes, and either received 'negative' outcomes where the fear of disease is quelled - or 'positive' outcomes - where although a persons' outlook may be bleaker, there is hope in resolving the affliction thanks to early treatment. Thus, an advantage of the medical patent system is the guarantee of 'cyclical' development, unhindered by uncertain, or uncontrollable, business-motivated competition ${ }^{8}$. With this in mind, one sees the main counter argument in defence of medical patents: medical patents are acceptable as they allow for more lives to be saved in the long run than if they were to not exist.

Technological - and consequently theoretical - innovation is an integral incentive for companies to invest in new technology and to share this information publicly. For instance, if a company could choose to either spend a large quantity of capital to try and invent some new product or could copy from a less-capable competitor with sure success, the latter would always be wiser without the existence of patents. The company would be incentivised to hoard capital until it saw some blossoming new invention which it could take and better produce with its greater manufacturing capacity. With patent law, the company would be forced to at least buy out the owners of the patent, which would still encourage innovation in a roundabout manner - in the context of this paper, furthering the 'cyclicality' of medical patents. This argument is supported largely due to the high cost of capital that is required to constantly innovate in the healthcare industry. While estimates have varied, one source puts the mean investment required to bring a new drug to market at about $\$ 1.3$ billion. 9 There are several important factors requiring the investment to be so expensive. First, new medicines have very lengthy R\&D processes as well as difficult clinical trials. Additionally, many clinical trials fail and require new research and development for medicines. Consequently, it is important to

\footnotetext{
8 Ibid, p35

9 Wouters (et.al). Estimated Research and Development Investment Needed to Bring a New Medicine to Market, 2009-2018, pp.844-853.
} 
create adequate monetary and moral incentives for innovation in the medical industry. Although companies may sometimes develop diagnostic tests without appropriate patent coverage, these sorts of tests are only done for basic experiments that have either a very low or decidedly scientifically unknown projected outcome. In some circumstances, companies may be excluded from entering relevant pharmaceutical markets if they do not provide the adequate incentives, and subsequently protections, for their R\&D funding applications ${ }^{10}$. Despite the obvious mechanisms attempting to provide rigidity to the medical patents sector, drug manufacturers are increasingly 'antigeneric medication' - what this means is that companies are resulting to a number of tactics to undermine the ' 1984 Drug Price Competition and Patent Term Restoration Act', which gave pharmaceuticals exclusive protection rights as a result of new drug innovations. Companies who successfully developed new therapies through the 1984 Act were well placed to assert monopolies on the markets, however, this was offset by an aggressive expiration schedule which encouraged any and all drug companies to manufacture non-brand name versions as "generics" 11 . Two common ways pharmaceuticals are undermining the widespread accessibility to generics are "pay for delay" agreements (where companies pay generic manufacturers to not release drugs), and "Citizens petitions" (where applications can be made, by corporations, to authorities such as the American FDA to deny or delay approvals of generics) ${ }^{12}$. The jeopardization of "generics" reflects a pharmaceutical industry allowing monopolies to run rampant - it runs counter to the 'cyclicality', the ideology behind the patent system itself: increased prosperity for inventors due to market monopoly realisation, enhanced reputations, recovered R\&D costs and increased welfare prosperity for those chiefly benefitting from their inventions ${ }^{13}$. Under the Utilitarian framework, it seems best to create laws that would save the most amount of people over the longest period of time. Forcing pharmaceuticals to innovate in line with the practices established through the 1984 Drug Price Competition and Patent

${ }^{10}$ Soini (et.a), Patenting and licensing in genetic testing, p.35

${ }^{11}$ Fox, How Pharma Companies game the System to Keep Drugs Expensive

12 Ibid

${ }_{13}$ Gubby, Is the Patent System a Barrier to Inclusive Prosperity? The Biomedical Perspective 
Term Restoration Act would likely be more beneficial than dismantling longstanding patent laws, leading to one-time injections of cheaper medicine into the market and subsequent 'free-flows' of less certifiable products.

While the theoretical argument is grounded in legislation and ideology of 'common-good' regulation, further broader study in empirical data is required to better contextualise the problems of medical patent reforms. According to data gathered by Brownyn H. Hall and Dietmar Harhoff in their 2012 study, healthcare is actually one of the few industries where the argument for utilitarian reform of patent rights is shown to be accurate, and desirable. It is generally recognised that the pharmaceutical industry is one of the few parts of the economy which sees a tangible increase in innovation due to patent rights. ${ }^{14}$ Furthermore, one study, detailed by Duncan S. Gilchrist in his 2016 work, examined the effect of "First-in-Class Exclusivity" in the USA to determine how they impact subsequent production of drugs by medical companies. ${ }^{15}$ There are two interesting takeaways from this study: First, it is suggested that an extra year of exclusivity and protection could lead to the subsequent net production of $25-30 \%$ subsequent entry, or 0.2 units/more drugs. From this, it is also implied that a standard deviation change (i.e. about 3 years) in the exclusivity period could have drastic effects on drug innovation. An exclusivity period one standard deviation shorter is expected to lead to o in the average class, and an increase by one standard deviation is expected to double the number of subsequent entries. It might be pointed out that this is not a direct measure of innovation. For instance, it could be the case that this is merely showing the introduction of small "updates" to existing drugs which warrants the renewal of a patent. While scepticism is appreciated, this is a difficult argument to prove or disprove. It is still useful to prove that good patent protection can show an increase in drug production, whereas bad protection can show a decrease in production.

An important part of this increase in production is the fact that new medicines require high research and development costs. This, in turn, requires strong patent rights in order for the product to be profitable. To view it in another

${ }^{14}$ Hall and Harhoff, Recent Research on the Economics of Patents, pp548-9

${ }_{15}$ Gilchrist, Patents as a Spur to Subsequent Innovation? Evidence from Pharmaceuticals, pp.189-221 
way, it seems that we can use research and development as a sign of innovation in the medical field. Indeed, if we follow the literature, this is another benefit of strong patent rights. Sunil Kanwar and Robert Everson, in their 2003 study, used cross-country data to examine the relationship between strong patent rights and levels of research and development. ${ }^{16}$ They argued that based on their data, a strong set of patent rights led to a direct increase in research and development spending. In fact, they even argue that the link could be stronger, had they been more careful in separating countries which only had strong rights De Jure and countries which had strong rights De Facto. Albert G.Z Hu and I.P. L Png expand on this idea, in their 2013 study, by instead examining the effect of IP law on economic growth. ${ }^{17}$ While they argued that strong IP rights could contribute to increased economic growth, they also advocate for a more nuanced view. It is argued that IP rights are most valuable for highly developed countries with particularly manufacture-focused economies. In particular it was important for countries with large patent-intensive industries (such as drug development). These two articles further advocate the benefits of a theoretical, utilitarian-minded approach to medical patents. While the Evenson article proves the beneficial effect of strong patent law on research and development, the Hu study shows that good IP law is essential for the strong economic growth of patent-intensive industries like the medical sector.

Returning to the "generic" drugs problem, this highlights the longstanding 'balancing' problem between monetary and moral incentives - it would be beneficial to explore more empirical examples of where this problem has exacerbated the issues of accessibility to the drugs themselves, and compromised the desired 'cyclicality' of medical patents. Such is traditionally called the "free-rider" problem: wherein companies which have not had to bear high research and development costs can take inventions and sell them for cheap, while profiting since they don't have to make up for earlier research costs. James Bessen, et.al, collect a variety of data in their 2011 study, to emphasise how especially problematic this imbalance is in the medical

\footnotetext{
${ }^{16}$ Kanwar and Evenson, Does Intellectual Property Protection Spur Technological Change, pp. 235264

${ }_{17} \mathrm{Hu}$ and Png, Patent Rights and Economic Growth: Evidence from Cross-country Panels of Manufacturing Industries pp.675-698
} 
industry. ${ }^{18}$ First it has been proved that two years after generic alternatives have entered prices drop to $37 \%$ of original value. This is perhaps why there is such a discrepancy in patent pursuits between medical companies and other sectors - as they suggest, firms applied for patents on $79 \%$ of pharmaceutical products as opposed to $36 \%$ of product innovations and $25 \%$ of process innovations. This seems to align with other research into this field. For instance, one paper suggested that a patent could cause a 40-50\% increase in the returns of an invention. ${ }^{19}$ With this in mind it should be easy to see why strong patent rights are important to the continued innovation and growth of a pharmaceutical company. In fact, there is even good reason to believe that weaker patent rights, on top of curbing innovation, could lessen access to important medicine. An analysis by Peter M. Cockburn, et.al, of this trend covers the launches of 642 new drugs across more than 70 countries. The 2016 paper argues that on-top of the ordinary costs of new drugs, every country's sale application has its own set of necessary and expensive costs, which puts even more pressure on drug companies to increase revenue. It is part of this which puts so much importance on patents and strong IP rights. It is then argued the best way to increase the diffusion and access to important drugs is to create long-lasting and strong IP rights. ${ }^{20}$ While the UK currently does not have to worry about gaining access to important drugs - thanks in large part to the National Health Services platform and robust maintenance of it - it is very likely that substantial changes in current IP/Patent laws - were they to provide weaker and shortened protective durations - would only serve to harm access to new medicine.

In closing, perhaps more important than extrapolating the theoretical, utilitarian, model's integrity is analysing whether UK legislation actually follows this justification for medical patents. It's important to recognise that medical patents already have a long (and controversial) history in UK legislation. The first recorded patent for medical remedy in England was introduced by John Dickson in 1620, and relates to "certain commodious

\footnotetext{
${ }^{18}$ Bessen and Meurer, Do Patents Perform Like Property? p15

${ }^{19}$ Jensen (et.al) Estimating the Patent Premium; Evidence from the Australian Inventor Survey, pp.1128-1138

${ }^{20}$ Cockburn (et.al) Patents and the Global Diffusion of New Drugs, pp. 136-164
} 
instrument called a back stall, back franie, or back skreene, for the ease and re liefe of such sick persons and others as are, or shall be, distempered or troubled with heate of theire backes through continual keeping or lye ing on theire beddes. ". In 1726 we can see Benjamin Okell's "Doctor Bateman's Pectoral drops". ${ }^{21}$ These examples are brought up, not because they prove a link between the theoretical model but because they point to a continued tradition in our legal system of patenting medical inventions. This tradition has faced criticism long before the modern criticisms of expensive medicines. In the 1930 s there was a great atmosphere of debate in the medical community over the ethics of patenting medicine. At its height 'The Conference of Medical Patents' (made up of representatives from the Royal Colleges of Physicians and Surgeons and the Medical Research Council) declared that "the granting of further patents in the medical field is undesirable in the public interest”. The reason given is that patents hinder research and discovery. ${ }^{22}$ Interestingly, an exception was created for "synthetic preparation of new substances". 23 This distinction is suggested to be based on the difference between the two categories of therapeutics. While patenting the use of biological material (e.g. vitamins, toxins, viruses) was seen to decrease innovation in the field, it was admitted (with German labs being used as an example) that synthetic patents could actually foster progress in the medical community. ${ }^{24}$ This isn't strictly a legal source however the arguments being used align not only with our theoretical model but with the legislative model of the modern UK.

To conclude, it seems that medical patents in their current form provide sufficient benefit to jurisdictions such as the United Kingdom. Theoretical arguments, advocating a more utilitarian, fair and crucially 'cyclical' model of regulating medical patents, are well-evidenced by historic problems with balancing monetary and moral obligations of inventors and pharmaceutical corporations in accordance with 'fair' legislative precedents on what constitutes a 'patent' within the context of multilateral and the medical sectors.

${ }_{21}$ "Early Medical Patents" The British Medical Journal, Vol. 2, No. 667; 1873

${ }^{22}$ "Conference on Medical Patents Unanimous Conclusions"; The British Medical Journal, Vol.1, No. $3725 ; 1932$

23 Ibid

${ }^{24}$ Ibid 
While pharmaceutical market price-regulations are in some jurisdictions - like the United States of America - offering outdated security or unfairly expensive to the chief consumers of the sector's products because of longstanding industry manipulation and exploitation, it is difficult to argue that they are unjustifiably utilitous or that this is a good enough reason to dismantle patent rights altogether. One preferable solution would be for major countries to subsidise the production of important medicines while also unifying global standards for drug testing, similar to the precedents established in the "1984 Drug Price Competition and Patent Term Restoration Act'. Though this wouldn't completely solve the price issue, it would dramatically decrease the price of medicines by putting a time-cap on monopolies and reintroduce true beneficial cyclicality into the pharmaceuticals market. 


\section{Bibliography}

"Conference on Medical Patents Unanimous Conclusions"; The British Medical Journal, Vol.1, No. 3725; 1932

"Early Medical Patents" The British Medical Journal, Vol. 2, No. 667; 1873

Bessen, James and Meurer, Michael J. "Do Patents Perform Like Property?”; Academy of Management Perspectives, Vol. 22, No. 3; Academy of Management; August 2008; pp.8-20

Cockburn, Iain M. and Lanjouw, Jean O. and Schankerman, Mark "Patents and the Global Diffusion of New Drugs"; The American Economic Review Vol. 106, No. 1; American Economic Association; January 2016; pp. 136164;

Fox, Erin, "How Pharma Companies game the System to Keep Drugs Expensive" (April 06, 2017) < https://hbr.org/2017/04/how-pharmacompanies-game-the-system-to-keep-drugs-expensive>

Gilchrist, Duncan S. "Patents as a Spur to Subsequent Innovation? Evidence from Pharmaceuticals"; American Economic Journal: Applied Economics, Vol. 8, No. 4; October 2016; pp. 189-221

Gubby, Helen, "Is the Patent System a Barrier to Inclusive Prosperity? The Biomedical Perspective”, Global Policy, vol.11: issue.1 (September 06, 2019)

Hall, Brownyn H. and Harhoff, Dietmar "Recent Research on the Economics of Patents"; Annual Review of Economics, vol. 4; Annual Reviews; 2012; pp. 541-565

Hu, Albert G.Z. and Png, I.P.L. "Patent Rights and Economic Growth: Evidence from Cross-country Panels of Manufacturing Industries"; Oxford Economic Papers, Vol. 65, No. 3 Special Issue: Innovation and Intellectual Property; Oxford University Press; July 2013; pp.675-698

Jensen, Paul H. and Thomson, Russel and Yong, Jongsay; "Estimating the Patent Premium; Evidence from the Australian Inventor Survey"; Strategic Management Journal , Vol. 32, No. 10; Wiley; October 2011; pp.1128-1138

Kanwar, Sunil and Evenson, Robert "Does Intellectual Property Protection Spur Technological Change"; Oxford Economic Papers, Vol. 55, No. 2; Oxford University Press; April 2003; pp. 235-264

Legislation. Gov, "Patents Act 1977" > https://www.legislation.gov.uk/ukpga/1977/37/section/1>

Legislation.Gov, "Patents Act 1949" < https://www.legislation.gov.uk/ukpga/Geo6/12-13-14/87/contents>

Slin, Judy Patents and the UK Pharmaceutical industry between 1945 and the 1970s, 
Soini, Sirpa, Ayme, Segolene, Matthijs, Gert "Patenting and licensing in genetic testing: ethical, legal and social issues", European Journal of Human Genetics, vol.16: issue 37 (2008) pp.10-50

Van Overwalle, Geertrui, "IPR Issues and High Quality Genetic Testing”, Quality Issues In Clinical Genetic Services, DOI 10.1007/978-90-481-39194_26 (March 3, 2010) pp.251-265, p256

World Intellectual Property Organisation, "Summary of the Paris Convention for the Protection of Industrial Property (1883)" <

https://www.wipo.int/treaties/en/ip/paris/summary paris.html>

Wouters, O.J. and McKee, M and Luyten, J. "Estimated Research and

Development Investment Needed to Bring a New Medicine to Market, 20092018”. JAMA. 2020;323(9):844-853. doi:10.1001/jama.2020.1166 